\title{
Mobilization of the Proteus mirabilis Chromosome by R Plasmid R772
}

\author{
By J. N. COETZ.EE \\ Department of Microbiology, University of Pretoria, Republic of South Africa
}

(Received 27 February 1978; revised 17 April 1978)

\begin{abstract}
The P-1 incompatibility group plasmid R772 can mobilize the chromosome of Proteus mirabilis strain PM5006. The decreasing gradient of recombinant recovery frequencies found for markers which were increasingly distal to $0 \mathrm{~min}$ with plasmid $\mathrm{D}$ donors was not found with R772. Instead, it produced recombinants for all markers at frequencies of about $5 \times 10^{-5}$ per donor. This is about 10 -fold lower than the plasmid transfer frequency. Recombinants were stable and recombination was only detected over short segments of the chromosome which corresponded to about $10 \mathrm{~min}$ on the D plasmid map of the chromosome. All recombinants had inherited R772 and expressed all properties of the plasmid. Attempts to isolate variant plasmids with increased frequencies of recombinant formation were unsuccessful.
\end{abstract}

\section{INTRODUCTION}

The recombinant plasmid P-lac $\overline{\mathrm{R} 1 d r d 19}$ (Coetzee, 1974) can mobilize the Proteus mirabilis chromosome (Coetzee, 1975, 1978). This plasmid (now named D) causes polarized transfer of a group of chromosomal markers with origin near his-1 (Fig. 1). Genetic circularity of the chromosome has not been demonstrated.

$\mathrm{R}$ plasmid R772 was identified in a strain of $P$. mirabilis isolated from clinical material (Hedges, 1975). It confers kanamycin resistance on bacterial hosts. Subsequently it was used to mobilize a non self-transmissible bacteriocinogenic plasmid Mor174 (Coetzee et al., 1977; Williams, 1977), and found to be a P-1 incompatibility group plasmid (unpublished). Since R772 could mobilize the Mor174 plasmid it was decided to test the chromosome mobilizing ability of R772. Coetzee (1978) reported an increased frequency of chromosomal recombinant recovery, with sex plasmid $\mathrm{D}$, when mating occurred on non-selective solid minimal medium at $30^{\circ} \mathrm{C}$. Because R772 belongs to the incompatibility group P-1, the mating conditions chosen were those mentioned above (see Dennison \& Baumberg, 1975; Towner \& Vivian, 1977; Haas \& Holloway, 1976). In preliminary investigations (Coetzee, 1978) R772 was found to possess sex factor activity in P. mirabilis and this aspect of the plasmid is reported here.

\section{METHODS}

Bacteria and plasmids. These are listed in Table 1.

Media. Nutrient broth was Oxoid no. 2 code CM67; nutrient agar was the same broth solidified with $1 \cdot 2 \%(w / v)$ Difco agar. MacConkey agar was from Difco. Minimal medium (MM) was that of Grabow \& Smit (1967). For auxotrophic strains this medium was supplemented with amino acids or uracil (each at $20 \mu \mathrm{g} \mathrm{ml}^{-1}$ ) when necessary. Incubation temperature was $30^{\circ} \mathrm{C}$ and media were brought to that temperature before inoculation.

Antibacterial drugs. Nalidixic acid $\left(500 \mu \mathrm{g} \mathrm{ml}^{-1}\right)$ was added to $\mathrm{MM}$ to counterselect donors in interrupted 
Table 1. Bacteria and plasmids

Bacteria
Proteus mirabilis
PM5006
UP3
UP4
UP14
UP19
UP21
UP37

UP39
UP47
UP49
UP77
UP177
UP433
UP466
UP476
UP477
UP500
Escherichia coli
J62-1
Plasmids
D
R772

Relevant properties

Wild-type strain resistant to tetracycline his-1 mutant of PM5006 nalAl pyrB1 mutant of PM5006 nalAl ura-l mutant of PM5006 str-1 ura-3 mutant of up18 (ser-2 str-2 his-1 nalAl) trp-3 mutant of UP16 (str-2 his-1 nalAl) leuB3 mutant of UP3

$\arg E 3$ mutant of UP3

leuB2 mutant of UP4

$\arg E 1$ mutant of UP4

$\operatorname{argE} 2$ mutant of UP7 (tyr-1 str-1)

cys $A 12$ gly-17 $\arg A 7$ mutant derived from

UP17 (pyrB2 str-2 his-1 nalAl)

cysC1 nalA1

met $F 2$ nalAI

metF6 mutant of UP477

leuB2 nalAl

rif- 1 mutant of UP4

Nalidixic acid resistant mutant of $\mathrm{J} 62$, an $\mathrm{F}^{-}$lac pro his trp $\mathrm{K} 12$ strain

$\mathrm{D}$ is the symbol for plasmid P-lac $\overline{\mathrm{R} 1 d r d 19}$ *. Carries markers lac ${ }^{+}$ACKSSu†

P-1 incompatibility group plasmid. Molecular (unpublished) weight about $27 \times 10^{6}$. Confers kanamycin resistance on hosts
Reference(s)

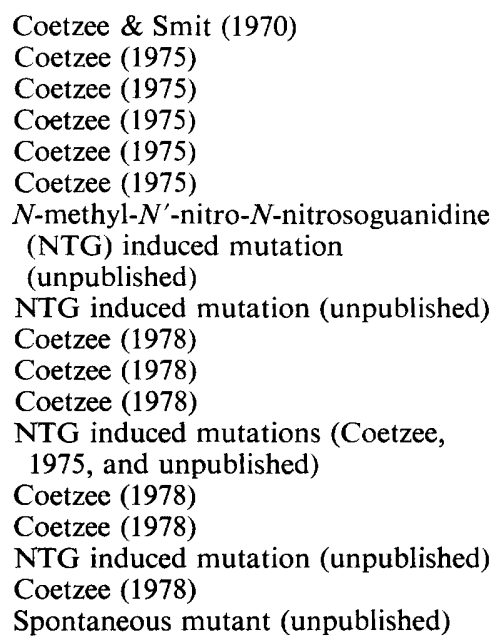

Clowes \& Hayes (1968)

Coetzee $(1974,1975,1978)$

* Superior line indicates transduced R plasmid. (Su).

$\dagger$ Resistance to ampicillin (A), chloramphenicol (C), kanamycin (K), streptomycin (S), sulphonamide

mating experiments. Kanamycin, tetracycline (each at $\left.50 \mu \mathrm{g} \mathrm{ml}^{-1}\right)$ or rifampicin $\left(500 \mu \mathrm{g} \mathrm{ml}^{-1}\right.$ ) were used in MM or MacConkey agar when necessary.

Plate matings. These were done by the method of Coetzee (1978). Briefly, mating mixtures were constituted on non-selective MM (i.e. supplemented with growth requirements of recipient and donor) and incubated for $6 \mathrm{~h}$ before harvesting in saline. Control experiments lacked either donor or recipient. After washing, suitable dilutions were plated on selective MM and incubated for $48 \mathrm{~h}$.

Construction of $P$. mirabilis UP strains containing plasmid R772 or D. The liquid mating technique of Coetzee et al. (1973) was used. Donors, J62-1(R772) or J62-1(D), were counterselected with tetracycline and transfer of both plasmids was selected with kanamycin. Plate mating was also employed for R772 transfer, with the donor counterselective agent as well as kanamycin incorporated in MM. Transfer of kanamycin resistance of plasmid $\mathrm{R} 772$ to various UP strains occurred in broth and on non-selective MM at frequencies of about $5 \times 10^{-4}$ per donor cell. Similarly plasmid D was readily transferred without affecting chromosomal markers of the strains (Coetzee, 1975). All donor strains were maintained on nutrient agar slopes containing kanamycin at $10^{\circ} \mathrm{C}$. They were subcultured at intervals of about 2 months.

Interrupted mating. The solid medium method of Haas \& Holloway (1976) was used.

Unselected marker analysis and recombinant stability. Recombinant clones were purified on agar similar to that used for selection. Single colonies were then suspended in $0.5 \mathrm{ml}$ saline and loopfuls were spotted on selective media and on the medium used for selection of the particular recombinant. Stability was tested for by plating a suitable dilution of an overnight broth culture of a purified recombinant clone on MacConkey agar. After overnight incubation the growth was replicated to selective MM.

$R$ plasmid characterization in chromosomal recombinants. Kanamycin resistance was tested by replication of patched colonies on MM to the same medium containing kanamycin. Ability to transfer kanamycin resistance to UP500 was tested by the liquid mating technique mentioned above using rifampicin for donor counterselection on MacConkey agar also containing kanamycin. The sensitivity of recombinants to phage 
Table 2. Recombination frequencies of markers using plasmids $\mathrm{D}$ and $\mathrm{R} 772$ as donors

Plate matings were done as described in Methods. Selective MM was supplemented, where necessary, with growth requirements for unselected recipient markers.

\begin{tabular}{|c|c|c|c|c|}
\hline Cross & Selected marker & Map location & Plasmid & $\begin{array}{l}\text { Recombination } \\
\text { frequency* }\end{array}$ \\
\hline IP477(D) or (R772) & his-I & $7 \mathrm{~min}$ & $\begin{array}{c}\mathrm{D} \\
\mathrm{R} 772\end{array}$ & $\begin{array}{l}3 \times 10^{-4} \\
4 \times 10^{-5}\end{array}$ \\
\hline $3(\mathrm{D})$ or $(\mathrm{R} 772)$ & pyrB2 & $20 \mathrm{~min}$ & $\begin{array}{c}\mathrm{D} \\
\mathrm{R} 772\end{array}$ & $\begin{array}{l}4 \times 10^{-5} \\
5 \times 10^{-5}\end{array}$ \\
\hline UP3(D) or (R772) & $\operatorname{cys} C I$ & $40 \mathrm{~min}$ & $\underset{\mathrm{R} 772}{\mathrm{D}}$ & $\begin{array}{l}8 \times 10^{-7} \\
4 \times 10^{-5}\end{array}$ \\
\hline P21(D) or (R772) & leuB2 & $\begin{array}{l}\text { Most distal } \\
\text { marker }\end{array}$ & $\underset{\mathrm{R} 772}{\mathrm{D}}$ & $\begin{array}{l}1 \times 10^{-7} \\
5 \times 10^{-5}\end{array}$ \\
\hline P21(D) or (R772) & $\arg E I$ & Unknown & $\underset{\mathrm{R} 772}{\mathrm{D}}$ & $\begin{array}{r}<5 \times 10^{-9} \\
8 \times 10^{-5}\end{array}$ \\
\hline
\end{tabular}

* Recovery of recombinants per donor cell in mating mixture.

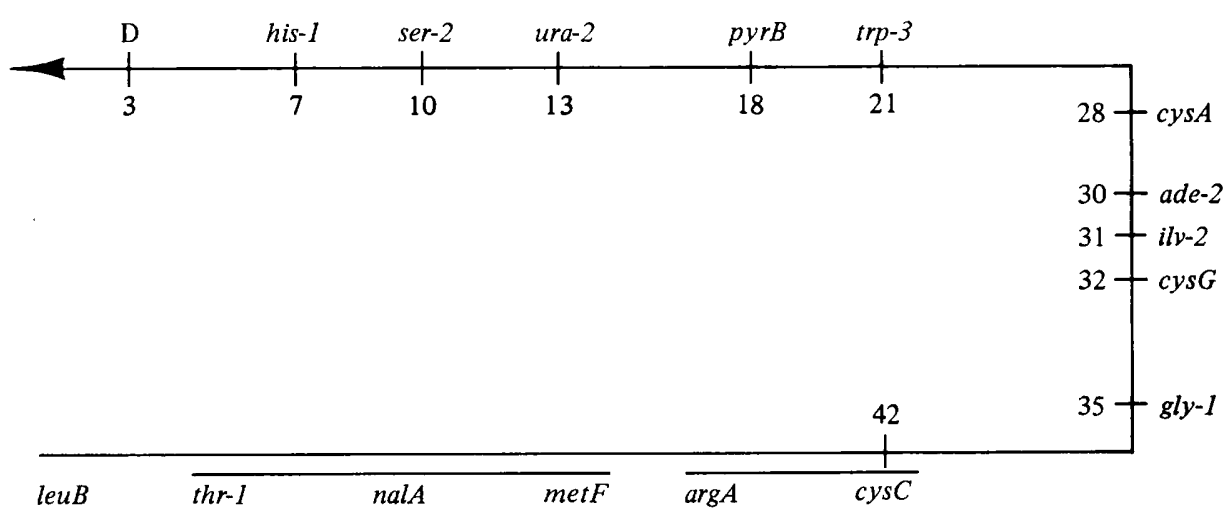

Fig. 1. The order of markers on the chromosome map of $P$. mirabilis. Where known, the approximate location relative to the plasmid D origin is given (in $\mathrm{min}$ ). Where the time of entry of markers is not known the spacing is arbitrary. A bar across markers indicates that their relative positions have not been determined (Coetzee, 1975, 1978, and unpublished).

PR772 was not tested, because phage sensitivity of $P$. mirabilis recombinants is not easy to determine (unpublished).

Chromosome donor ability (Cda) (Haas \& Holloway, 1976) was measured by replication of patched auxotrophic recombinant colonies on suitably supplemented MM to MM recently surface-seeded with UP4. Selection was for pyr $B$ recombinants.

\section{RESULTS}

\section{Inheritance of chromosomal markers}

Transfer. Marked differences in frequencies of recombinant recovery were noted using plasmids D and R772 as donors (Table 2). With plasmid D the recovery of recombinants for four markers, dispersed over the entire linkage group (Fig. 1), showed typical polarization with frequencies per donor cell which varied between $3 \times 10^{-4}$ and $1 \times 10^{-7}$. With plasmid R772 recombinant recovery frequencies were similar (at about $5 \times 10^{-5}$ ) for the four markers concerned. A fifth marker, $\arg E 1$, which had failed to produce recombinants in plasmid D-mediated transfer (Coetzee, 1978), again did not produce recombinants under promotion of this plasmid, but recombinants were produced when the donor carried R772. All progeny were stable and behaved like haploid recombinants (Meade \& Signer, 1977). 
Table 3. Segregation of unselected markers in crosses

Plate matings were done as described in Methods. Selective MM was supplemented with growth requirements for unselected recipient markers. For each selected marker, the first row of results is for the cross UP $177 \times$ UP476(R772) and the second row is for the cross UP $177 \times$ UP433(R772).

\begin{tabular}{|c|c|c|c|c|c|}
\hline \multirow[b]{2}{*}{ Selected marker } & \multicolumn{5}{|c|}{$\begin{array}{c}\text { Co-inheritance of unselected chromosomal } \\
\text { markers }(\%)^{*}\end{array}$} \\
\hline & his $^{+}$ & $p y r^{+}$ & cys $^{+}$ & $g l y^{+}$ & $\arg ^{+}$ \\
\hline his- $I^{+}$ & - & $\begin{array}{l}7 \\
8\end{array}$ & $\begin{array}{l}0 \\
0\end{array}$ & $\begin{array}{l}0 \\
0\end{array}$ & $\begin{array}{l}0 \\
0\end{array}$ \\
\hline pyrB2 $2^{+}$ & $\begin{array}{r}8 \\
11\end{array}$ & - & $\begin{array}{l}4 \\
6\end{array}$ & $\begin{array}{l}1 \\
0\end{array}$ & $\begin{array}{l}0 \\
1\end{array}$ \\
\hline $\operatorname{cys} A 12^{+}$ & $\begin{array}{l}6 \\
6\end{array}$ & $\begin{array}{l}25 \\
19\end{array}$ & - & $\begin{array}{l}3 \\
6\end{array}$ & $\begin{array}{l}0 \\
0\end{array}$ \\
\hline$g l y-17^{+}$ & $\begin{array}{l}0 \\
0\end{array}$ & $\begin{array}{l}6 \\
0\end{array}$ & $\begin{array}{l}31 \\
27\end{array}$ & - & $\begin{array}{l}1 \\
7\end{array}$ \\
\hline $\arg A 7^{+}$ & $\begin{array}{l}0 \\
0\end{array}$ & $\begin{array}{l}0 \\
0\end{array}$ & $\begin{array}{l}3 \\
6\end{array}$ & $\begin{array}{l}46 \\
39\end{array}$ & - \\
\hline
\end{tabular}

* One hundred recombinants for each selected marker were tested for the presence of unselected markers by the procedure described in Methods.

Segregation of unselected markers. Using strain UP177 (his-1 pyrB2 cysA12 gly-17 argA7) as recipient and donor strains UP476(R772) and UP433(R772), with contraselection markers leuB2, metF6 and cysCI respectively, sets of linkage data were obtained (Table 3 ). These results are consistent with there being only one chromosomal transfer event per recombinant and with the marker order derived from the use of plasmid D. Although data for the time of marker entry is not satisfactory (Coetzee 1975, 1978), it is evident that recombinants may seldom inherit lengths of donor chromosome longer than about $10 \mathrm{~min}$ on the $\mathrm{D}$ plasmid map.

To demonstrate genetic circularity of the chromosome, attempts were made to show co-inheritance of the proximal marker his-1 with leuB3. The latter marker is an allele of the most distal marker leuB2 on the D plasmid map and is carried by strain UP37. Strain UP39 was also used; this strain carries an allele of $\operatorname{argE1}$, a marker which did not yield recombinants (Coetzee, 1978) and is presumably located distally to leuB2. Strain UP466(R772) was used as donor in the former cross, and UP14(R772) in the latter. Both crosses were sterile.

Interrupted mating. Using some recipient strains employed before (Coetzee, 1978) and the same donor now carrying R772, a marked difference was noted between times of entry of chromosomal markers and the times previously recorded for plasmid D-mediated chromosomal transfer (Coetzee, 1975, 1978). With plasmid D, individual chromosomal markers entered between 7 and $42 \mathrm{~min}$. Under promotion of R772, recombinants for all markers registered between 4 and $7 \mathrm{~min}$. The above findings were confirmed by crossing the multiply marked recipient strain UP177 and donor UP77(R772). Recombinants of each individual marker selected registered between 4 and $7 \mathrm{~min}$ (not shown). These results, as well as those presented in Table 2, indicate that plasmid R772 has many sites on the chromosome from which chromosome mobilization may be initiated. Plasmid R772 transfer, like that of D (Coetzee, 1975, 1978), was early and occurred at high frequency.

\section{Properties of plasmid $\mathrm{R} 772$ in chromosomal recombinants}

All of hundreds of purified recombinants derived from the experiments presented in Table 3 were kanamycin resistant, could transfer the marker and possessed Cda. To test for enhanced $\mathrm{Cda}, 10$ auxotrophic recombinants from each of crosses 1, 4, 5 (Table 2) and 
all crosses of Table 3 were mated with UP4 with selection for $p y r B^{+}$recombinants. Recombinants were recovered from all crosses at frequencies similar to those recorded in Table 2.

\section{DISCUSSION}

Plasmid R772 is the latest addition to the P-1 incompatibility group plasmids (Bryan et al., 1973; Haas \& Holloway, 1976) which can promote chromosome transfer in particular bacterial species. Chromosomal transfer by P plasmids may be strain specific (Stanisich \& Holloway, 1971; Stanisich \& Richmond, 1975). With other P-1 plasmids the requirements for donor ability are less strict but still very specific. Thus RP4 does not mobilize the Pseudomonas aeruginosa chromosome (Stanisich \& Holloway, 1971; Haas \& Holloway, 1976), has only marginal activity in Rhizobium leguminosarum (Beringer \& Hopwood, 1976) but promotes chromosome transfer in R. meliloti (Meade \& Signer, 1977) and Acinetobacter calcoaceticus (Towner \& Vivian, 1976a, b, 1977). Another member of the P-1 group, R68.45, promotes chromosome transfer in strains of Ps. aeruginosa, Ps. putida (Haas \& Holloway, 1976), R. leguminosarum, E. coli (Beringer \& Hopwood, 1976) and R. meliloti (Kondorosi et al., 1977), but fails to do so in $P$. mirabilis (unpublished observations). Specificity is thought (Jacob et al., 1976, 1977) to depend on the presence of homologous insertion sequences (ISs) on chromosome and plasmid, respectively, in much the same manner as the $\mathrm{F}$ factor of $E$. coli mobilizes that chromosome (Hu et al., 1975). Jacob et al. (1977) presented evidence that R68.45, a variant of plasmid R68 which shows enhanced $\mathrm{Cda}$, has a molecular weight that is $1.4 \times 10^{6}$ higher. This is consistent with the acquisition of an IS.

The present failure to isolate variants of $\mathrm{R} 772$ with $\mathrm{Cda}$ greater than about $5 \times 10^{-5}$ per donor could mean that the wild-type R772 already possesses the optimal number of suitable homologies required for $P$. mirabilis chromosome mobilization. These homologous areas must be stable, since, although R772 was first detected in P. mirabilis (Hedges, 1975), it was transferred to an $E$. coli strain which served as the source of $\mathrm{R} 772$ for the present investigation. Plasmid R772 has multiple sites of origin of chromosome transfer on the Proteus chromosome (Table 2) and apparently mobilizes fairly short segments of the donor chromosome (Table 3; Fig. 1). Both these plasmid properties also apply to R68.45-mediated chromosome transfer in Ps. aeruginosa (Haas \& Holloway, 1976), but it has not been determined whether the limited chromosome transfer is due to fragile mating pair formation or to some inherent property of the sex factors concerned. In $R$. leguminosarum R68.45 also transfers the chromosome from multiple sites but the size of transferred fragments varies and some may encompass one-seventh of the chromosome (Beringer et al., 1978). With R. meliloti (Meade \& Signer, 1977; Kondorosi et al., 1977) there are also multiple sites of origin for chromosomal transfer by R plasmids RP4 and R68.45, but large segments of chromosome are transferred. This could point to defects in mating pair formation in the $P$. mirabilis, PS. aeruginosa and, possibly, $R$. leguminosarum systems mentioned above. A phenomenon that may be related to the above is the fact that markers distal to the selected marker on the D plasmid map of $P$. mirabilis rarely yielded recombinants (Table 3 ). Pearce \& Meynell (1968) encountered a similar phenomenon with plasmid R1-mediated chromosome transfer in E. coli and Coetzee (1975) also noted it with D-promoted recombination in P. mirabilis.

Failure to demonstrate polarized transfer of chromosome markers in R772-promoted transfer may be attributed to multiple origins of chromosome transfer. The polarized transfer mediated by a single plasmid is then obscured (and levelled out) in the population as a whole by similar events occurring independently and concurrently from other origins. Should there be only one preferred site of plasmid chromosome interaction, donor efforts tend to become synchronized with resulting polarized transfer of genetic markers. This latter state may apply to $P$. mirabilis chromosome transfer by plasmid D (Coetzee, 
1975) and RP4-mediated chromosomal transfer in A. calcoaceticus (Towner \& Vivian, $1976 a, b)$.

R772 was inherited apparently unaltered by all chromosomal recombinants. A similar situation exists for R68.45-promoted chromosomal recombinants of $R$. leguminosarum where the $\mathrm{R}$ plasmid does not appear to lose any of its functions in recombinants (Beringer et al., 1978). This is unlike the fate of R68.45 in Ps. aeruginosa (Haas \& Holloway, 1976) or $R$. meliloti (Kondorosi et al., 1977) recombinants produced by mediation of this plasmid; in many of these recombinants plasmid function was either completely lost or only partially present. A similar situation could exist in RP4-promoted chromosomal recombinants of A. calcoaceticus (Towner \& Vivian, 1976b). A reason given for this instability (Jacob et al., 1977 ) is that ISs may promote deletions in genes near insertion sites (Weisberg \& Adhya, 1977). On these grounds it may be argued that if insertions and deletions do occur in R772 (but see Bennett et al., 1977) they take place at sites which do not affect the phenotype of the plasmid.

The isolation of a further sex factor for $P$. mirabilis PM5006 adds to the genetic versatility of the strain. The ability of R772 to mobilize distal markers on the D plasmid map of that organism may provide proof of the genetic circularity of the chromosome although the limited segments of chromosome over which recombination takes place could be a temporary limitation.

The author is in receipt of grants from the South African Medical Research Council.

\section{REFERENCES}

Bennett, P. M., Grinsted, J. \& Richimond, M. H. (1977). Transposition of TnA does not generate deletions. Molecular and General Genetics 154, 205-211.

Beringer, J. E. \& Hopwood, D. A. (1976). Chromosomal recombination in Rhizobium leguminosarum. Nature, London 264, 291-293.

Beringer, J. E., Hoggan, S. A. \& Johnston, A. W. B. (1978). Linkage mapping in Rhizobium leguminosarum by means of $\mathrm{R}$ plasmid-mediated recombination. Journal of General Microbiology 104, 201-207.

Bryan, L. E., Semaka, S. D., Van den Elzen, H. M., Kinnear, J. E. \& Whitehouse, R. L. S. (1973). Characteristics of R931 and other Pseudomonas aeruginosa $\mathrm{R}$ factors. Antimicrobial Agents and Chemotherapy 3, 625-637.

Clowes, R. C. \& HAYES, W. (1968). Experiments in Microbial Genetics. Oxford and Edinburgh: Blackwell Scientific Publications.

Coetzee, J. N. (1974). Properties of Proteus and Providence strains harbouring recombinant plasmids between P-lac R1drd19 or R447b. Journal of General Microbiology 80, 119-130.

Coetzee, J. N. (1975). Chromosome transfer in Proteus mirabilis mediated by a hybrid plasmid. Journal of General Microbiology 86, 133-146.

Coetzee, J. N. (1978). Extension of a chromosome linkage group of Proteus mirabilis. Journal of General Microbiology 107, 155-164.

Coetzee, J. N. \& Smit, J. A. (1970). Properties of Proteus mirabilis phage 13vir. Journal of General Virology 9, 247-249.

Coetzee, J. N., Datta, N., Hedges, R. W. \& Appelbaum, P. C. (1973). Transduction of $\mathbf{R}$ factors in Proteus mirabilis and $P$. rettgeri. Journal of General Microbiology 76, 355-368.

Coetzee, J. N., Krizsanovich-Williams, K. \& Williams, J. A. (1977). Cotransduction of morganocinogenic plasmid 174 and R factor R772. Journal of General Microbiology 100, 299-308.

Dennison, S. \& Baumberg, S. (1975). Conjugational behaviour of $\mathrm{N}$ plasmids in Escherichia coli $\mathrm{K} 12$. Molecular and General Genetics 138, 323-331.

Grabow, W. O. K. \& Smit, J. A. (1967). Methionine synthesis in Proteus mirabilis. Journal of General Microbiology 46, 47-57.

HaAs, D. \& Holloway, B. W. (1976). R factor variants with enhanced sex factor activity in Pseudomonas aeruginosa. Molecular and General Genetics 144, 243-251.

Hedges, R. W. (1975). R factors from Proteus mirabilis and $P$. vulgaris. Journal of General Microbiology 87, 301-311.

Hu, S., Ohtsubo, E. \& Davidson, N. (1975). Electron microscope heteroduplex studies of sequence relations among plasmids of Escherichia coli: structure of $\mathrm{F} 13$ and related $\mathrm{F}$ primes. Journal of Bacteriology 122, 749-763.

JaCob, A. E., Cresswell, J. M., Hedges, R. W., Coetzee, J. N. \& Beringer, J. E. (1976). Properties of plasmids constructed by in vitro insertion of DNA from Rhizobium leguminosarum or Proteus mirabilis into RP4. Molecular and General Genetics 147, 315-323.

JACOB, A. E., Cresswell, J. M. \& Hedges, R. W. (1977). Molecular characterization of the $\mathbf{P}$ group plasmid R68 and variants with enhanced chromosome mobilizing ability. FEMS Microbiology Letters 1, 71-74. 
Kondorosi, A., Kiss, G. B., Forrai, T., Vincze, E. \& Banfalvi, Z. (1977). Circular linkage map of Rhizobium meliloti chromosome. Nature, London 268, 525-527.

Meade, H. M. \& Signer, E. R. (1977). Genetic mapping of Rhizobium meliloti. Proceedings of the National Academy of Sciences of the United States of America 74, 2076-2078.

Pearce, L. E. \& Meynell, E. (1968). Specific chromosomal affinity of a resistance factor. Journal of General Microbiology 50, 159-172.

Stanisich, V.A. \& Holloway, B. W. (1971). Chromosome transfer in Pseudomonas aeruginosa mediated by R factors. Genetical Research 17, 169-172.

Stanisich, V. A. \& Richmond, M. H. (1975). Gene transfer in the genus Pseudomonas. In Genetics and Biochemistry of Pseudomonas, pp. 163-190. Edited by P. H. Clarke and M. H. Richmond. London: Wiley.
ToWner, K. J. \& Vivian, A. (1976a). RP4-mediated conjugation in Acinetobacter calcoaceticus. Journal of General Microbiology 93, 355-360.

TOWNeR, K. J. \& Vivian, A. (1976b). RP4 fertility variants in Acinetobacter calcoaceticus. Genetical Research 28, 301-306.

TOWNER, K. J. \& Vivian, A. (1977). Plasmids capable of transfer and chromosome mobilization in Acinetobacter calcoaceticus. Journal of General Microbiology 101, 167-171.

WeisberG, R. A. \& AdHYA, S. (1977). Illegitimate recombinations in bacteria and bacteriophage. Annual Review of Genetics 11, 451-473.

WILliams, J. A. (1977). Mobilization of Morganocin 174 plasmid and kinetics of morganocin production in Proteus and Escherichia coli hosts. Antimicrobial Agents and Chemotherapy 11, 514-520. 